\title{
Water damages in HVAC, tap water and sewage systems in cold climates
}

\author{
Christian Mattsson ${ }^{1 *}$, Birgitta Nordquist $^{1}$, Dennis Johansson ${ }^{1}$, Petter Wallentén ${ }^{2}$, and Hans Bagge ${ }^{2}$ \\ ${ }^{1}$ Division of Building Services, Department of Building and Environmental Technology, Faculty of Engineering, Lund University, \\ Box 118, 221 00, Lund, Sweden \\ ${ }^{2}$ Division of Building Physics, Department of Building and Environmental Technology, Faculty of Engineering, Lund University, \\ Box 118, 221 00, Lund, Sweden
}

\begin{abstract}
Water damages in buildings in the Nordic countries results in costs amounting to several billion Euros each year as well as a great deal of unpleasantness. The vast majority of the water damages cost in Sweden is caused by leaks from buildings services in the form of piping such as tap water, sewage, drainage and heating, as well as through insufficiently waterproof layers in wet rooms. The economic potential for making measures to prevent water damages on building services and wet rooms is enormous and savings could be used for other sustainability measures in the built environment. The aim of this paper is to review statistics of damages caused in cold outdoor climates. This is done by an analyse of empirical damage statistics by a literature review of both scientific literature and in retrievable cases from practical experience. The result will be a help to focus on the right damage types in colder climate and will make a foundation for future research on how to prevent water damages. The cold climate in the Nordic countries seems to be a factor for the number of water damages due to freezing that are described in the statistics and it could be established that the impact of the climate should be considered and that it need to be constructed and designed for in a larger extent.
\end{abstract}

\section{Introduction}

Water damage in buildings in the Nordic countries is a problematic area and amounts to a cost to society of some 1 billion EUR for homeowners and insurance companies each year [1]. In Sweden, the cost for just homeowners 2019 amounted to some 3,9 billion SEK (approximately 0.39 billion EUR) in insurance reimbursements from water damages in buildings [2]. In Denmark, the cost amounted to some 2,2 billion DDK (approximately 0.22 billion EUR) in insurance reimbursements [3]. In Norway, the cost amounted to some 3,4 billion NOK (approximately 0,34 billion EUR) in insurance reimbursements [3]. Water damages in buildings also contributes to other problems than cost related issues. It brings the homeowners discomfort and time-consuming work to restore the buildings to good shape. To reduce the amount of water damages in the Nordic countries, there are ongoing projects and incentives to educate builders and to stipulate rules and codes to build buildings with less water damages. These incentives have probably had a positive effect on the number of water damages in buildings in the years prior to this study [1]. The occurrence of water damages in buildings shows a positive trend and are decreasing for every year, but the problematic area is that the costs for the damages are increasing and shows a negative trend [2]. In Sweden, the cases of water damages were, according to Svensk Försäkring [2], in 1985 approximately 110000 and 2019 were the cases 75000 and a similar trend could be found in Norway and Denmark but in a shorter time span. However, considering the still large-scale amount of cases and the vast costs more knowledge is needed.

Causes for water damages in buildings in Sweden according to Vattenskadecentrum [1] are bursting or leaking pipes in wet-rooms and kitchens, which causes approximately $58 \%$ of the water damages in Sweden [1]. Other causes for water damages in buildings are appliances which stands for $25 \%$ of the water damages in Sweden and the last $17 \%$ of water damages could be derived from inadequate waterproof membranes in wet rooms with a floor drain [1]. Bursting and leaking pipes from tap water, sewage, drainage, and heating and damages in the waterproof membrane in the interior environment of the building is covered by this paper. This study aims to review statistics on water damages and costs in cold climates such as in the Nordic countries and add research about damages that could be related to cold climates; freezing damages and to examine to what extent cold climates do impact the number and costs of water damages.

\footnotetext{
* Corresponding author: christian.mattsson@hvac.lth.se
} 


\section{Research methodology}

A literary review and analysis of water damages with focus on cold climates in the Nordic countries was conducted in this study. The Nordic countries that were analysed were Sweden, Norway, and Denmark (due to the similarities in construction methods and climate). Because of similarities and that the climate are similar but with a slight difference between the most northern country (Norway) and the most southern country (Denmark) it allowed for the study to analyse water damages due to freezing in water pipes in buildings with same preconditions. An empirical statistical review of water damages was conducted based on actual cases and costs of water damages in buildings in the studied countries.

The international perspective was taken in consideration in the literary review by analysing literature on water damages in warmer climates. The literature review was based on the reasons for defects and flaws in the building sector that could lead to water damages. A scientific database search was used to conduct the searches. The scientific databases that were used in the study were Elsevier's Scopus, Engineering Village and the scientific database Web of Science. The defects that the literary review focused on were not limited to damages in the Nordic countries but to general defects and flaws in the building sector that could lead to water damages in the indoor environment. Both scientific literature and grey literature, such as governmental papers, was used in the review. The study aimed to answer the question of where and if there was a gap in the research on water damages, mostly focused on water damages due to freezing and cold climate.

An empirical statistic review of water damage cases and cost were conducted by gathering statistics of actual cases and costs for reimbursement from insurance companies. The gathering of cases and cost for damages was conducted from the different country's statistic gathering company. The data that was gathered in the study was the number of water damages that has occurred in each country during a timespan between 2000 and 2019. This timespan included buildings of any stage of its lifecycle. Measurements of occurrence and cost for water damages in Sweden, Norway and Denmark are carried out by the insurance companies. The insurance companies documents and inspects the water damage and could offer a reimbursement to the homeowner to cover the cost for the restoration of the damage. The costs for reimbursements and the number of cases are documented by the different insurance companies. The damage does only appear in the statistics if the homeowners report the damage to the insurance companies and if the deductible cost is lower than the cost of the restoration of the damage. The deductible cost is a number decided by the insurance company which the homeowner has to pay themselves. The part of the renovation cost that is not covered in the reimbursement. An area that has a lower coverage of water damages in the statistics are apartment blocks.
Damages in apartment blocks could have a higher deductible cost than dwellings and most often a common property manager that could restore the damage to a lower cost than the deductible cost from the insurance company and therefore the damages does not appear in the statistics. Another part of the building stock that is not covered by the statistics from the insurance companies are the buildings that does not have a coverage of insurance, e.g., building owned by the government or state. Hence the costs and the number of cases that occur in these kinds of buildings are not included in the statistics presented by the insurance companies. The buildings studied were the buildings covered by the insurance company's statistics, which are mostly represented by single-family houses. Building types that are not covered by the statistic, at the same extent as single-family houses, are apartment blocks, offices and uninsured buildings, for example, public buildings and schools. This is a problematic area by itself and will not be covered by this paper, still the quantity of water damages in buildings covered by the statistics is large and it is assumed to be a representative selection of the water damages that occurs in buildings in the Nordic countries.

Water damages occurs due to a vast number of reasons, this paper covers the water damages in the indoor environment. Water damages are categorized in different systems depending on the country. The Swedish water damage statistics by Svensk Försäkring [4] are categorized in pipes and appliances, and damages in the waterproof membrane of wet rooms. The categorization and the subcategories used in Sweden are described in Table 1.

Table 1. Categories used in Sweden for describing water damages [1].

\begin{tabular}{|l|l|}
\hline Causes & Subcategory \\
\hline \multirow{4}{*}{ Pipe system } & Corrosion \\
\cline { 2 - 2 } & Age or wear \\
\cline { 2 - 2 } & Defect products \\
\cline { 2 - 2 } & Wrongful installation \\
\cline { 2 - 2 } Service and appliances & Freezing \\
\hline Waterproof membrane & Hoses \\
\cline { 2 - 2 } & Machines \\
\hline & Walls \\
\cline { 2 - 2 } & Floors \\
\hline
\end{tabular}

The categorization of the water damages are organized by insurance companies and are carried out by an authorised damage investigator and in some case by an inquiry document, for example, the inquiry document by Vattenskadecentrum [4].

The Norwegian statistics by Finans Norge [3] are being categorized depending on the cause of the water damage, e.g., failure of the product, corrosion and freezing. The categorization for water damages used in Norway are described in Table 2. 
Table 2. Categories used in Norway for describing water damages [3].

\begin{tabular}{|l|}
\hline Causes \\
\hline Defect product \\
\hline Faulty design \\
\hline Wrongful installation \\
\hline User fault \\
\hline Tear or older than 30 years \\
\hline Corrosion \\
\hline Stop in sewages \\
\hline Freezing \\
\hline
\end{tabular}

The danish water damage statistics by Forsikring \& Pension [5] is categorized in a system based on the cause of the water damage, e.g., water damages which originates due to hidden pipes and connections and water damages that originates due to other reasons than hidden pipes and connection and exterior influence. The categories used in Denmark are described in Table 3.

Table 3. Categories used in Denmark for describing water damages [6].

\begin{tabular}{|l|}
\hline Causes \\
\hline $\begin{array}{l}\text { Water damages that originates from defect pipes or } \\
\text { connections }\end{array}$ \\
\hline $\begin{array}{l}\text { Water damages that originated from other reasons than } \\
\text { pipes, connections, storm, rain or snow }\end{array}$ \\
\hline Cold or freezing \\
\hline
\end{tabular}

The empirical damage statistics will also be analysed in an aspect of water damages due to freezing and to what extent the cold climate in the Nordic countries in this aspect affects number of water damages in buildings. The water damages that have been categorised by the insurance companies due to freezing were evaluated in a percentage of reported cases in the chosen timespan and compared to the yearly winter mean temperature deviation for each studied country.

\section{Results}

\subsection{Literature review}

From the literature review of water damages and defects in buildings was structured in two parts, the grey literature form governmental institutes and industry organizations in the Nordic countries and the scientific literature within the subject.

National board of housing, building and planning in Sweden, Boverket, carried out a compilation of defects and damages in the Swedish building industry. The aim was to investigate and evaluate solutions to reduce the number of defects and systematic building failures in the industry by conducting a study with interviews, surveys and gathering of statistics of defects [7]. The study resulted in a conclusion that most of the defects in the Swedish building sector occurs in effect of water and moisture in buildings and that the number of the most common defects was constant during the latest 10-year period. This, Boverket finds worrying because of the increasing number of buildings that are being build each year. Boverket states that this could lead to an increase of damages and defects. Boverket determined that the most common defects that occurred was due to shortage of time, lack of competence or resources, and the deficiency in communication and experience feedback within the own organisation.

A comprehensive compilation of Swedish water damage cases has been carried out before and the recent follow-up study was conducted 2015 based on the VASKA-project in Umeå 1987. The VASKA-project in 1987 was aimed to minimize risk for water damages with a thorough project descriptions and a control of the building process [8]. The study 2015 showed that VASKA-project succeed in the aim to reduce the risks of water damages in both apartments and single-family houses [9]. With the strategic work and the control of execution they found that the building within the VASKA-project had less defects in the building process and with the accurate and thorough monitoring the risk for water damages could be reduced significantly within the buildings in the VASKA-project.[9].

A study of seven building projects in Sweden carried out by Josephson and Hammarlund [10] had the focus on various defects in the building sector. The study was carried out in two parts, the first aimed to evaluate the different defects and costs that occurs in Swedish buildings and the second one aimed to evaluate the cause for the defects. By monitoring the building site and the production phase of seven building projects the study determined, in resemblance with Boverket, that many of the causes of defects occurred because of organisational aspects. The lack of motivation, e.g., forgetfulness and carelessness, and lack of information or knowledge was also common aspects that lead to defects in the building.

The international perspective of water damages in the indoor environment in buildings are limited and focuses on most of the same aspects of the problem as Josephson and Hammarlund [10], defects in buildings. Studies on defects has the focus of various defects in buildings but the ones of interest for this study are the literature that focuses on water damages caused by bursting pipes and inadequate installations and utilities. Chew and De Silva [11] identified 14 important risk factors in wet areas by assessing 56 high-rise nonresidential buildings. The study were conducted of interviews with keypersons in the building organisations and site surveys. Results indicated that water leakages were the defect that occurred most frequently in the studied buildings. The causes were located to deficient construction, material, design and maintenance practice. Similar problems and solutions were found in the study 
for Defects in affordable housing projects in Klang Valley, Malaysia by Abdul-Rahman, et al. [12]. The authors studied different kinds of buildings in this study and found similar problems and defects.

That the most common reason for that defects occurs seems likely to be because of organisational and design aspects. Several of the studied building projects in the literature review assess this as the main problematic area [13-15]. Whether water damages and water damages due to freezing could be related to defects in the entire building sector as described in the literature could be questioned but since the problematic area seems to be in the design and the organisation phase of the building it does seem likely that the problematic areas also occur in the damage categories this study treats. One aspect that was not clearly specified in the literature was the differences in location of the water pipes that are more exposed to the outdoor climate. One example of this are the water faucet that are placed outside of the building and have pipes that reaches though the insulation and are therefore exposed to the colder climate. If this part of the water system is not designed for being exposed to a colder climate, it could become a part that leads to water damages in the building. Hence causes for defects in the literature are most likely to be similar for the water damages due to freezing that are not covered by the scientific literature found in this study. In the Nordic countries there are examples of literature that cover this possible risk. For example, the industry rules from Säker Vatten [16], is one set of rules and instructions on how the buildings should be built to reduce the amount of water damages. However, these kinds of regulations seems to be missing on an international basis.

\subsection{Statistic review}

The empirical statistical review of water damages in the Nordic countries are presented as the statistical data of water damage from the different companies with both number of damages and costs of reimbursements from the insurance companies. The results were divided in three parts, with each part representing one of the studied countries. The separation of the statistics are made because of the different categories that each county describes the water damages that occurs. To not compare different water damage categories for each county the statistics are divided with each country's specific input to the water damage statistics as described in the research methodology.

Water damages in Sweden from Svensk Försäkring are presented as damages from water in different kinds of insurance principles. Damages from water were described as a damage that has occurred due to leakage, moisture or freezing from waterpipe or another reason that is not a natural damage [2]. The statistical data is gathered each year and dates to 1985 . As a complement to the statistics from Svensk Försäkring publish Vattenskadecentrum each year a water damages investigation, Vattenskadeundersökningen, with more descriptive information and in-depth analysis of the causes for the water damages in Sweden.

The number of water damages and cost between 1985 and 2019 in Sweden is presented in Figure 1. No specific costs for freezing damages are presented in the statistics and therefore in opposite of Norway and Denmark the cost for the freezing damages are not presented.

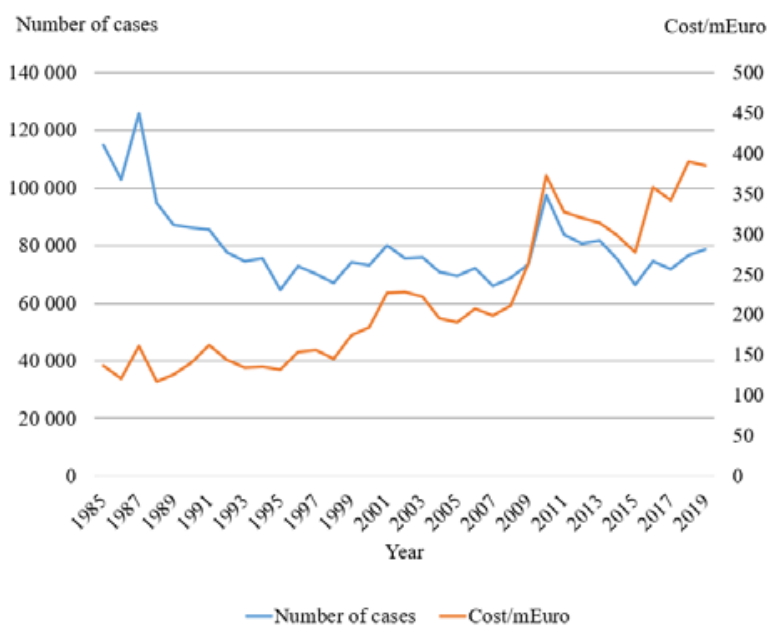

Figure 1. Number and cost of water damage cases in Sweden between 1985 and 2019 [2].

The Norwegian water damage statistics are gathered from the Norwegian financial organization, Finans Norge, which are responsible for the presentation of statistics from the insurance market. The water damages are sorted in different categories that describes where the water damages occurred. The categories chosen for this study are the ones that occurred in the indoor environment. These were, leakage in pipes and sewage, utilities that are connected to the water supply, heating distribution and installations in wet rooms. The timespan of the statistic were between 2008 and 2019 [3]. The number of water damage cases, cost and cost for freezing damages between 2008 and 2019 in Norway is presented in Figure 2.

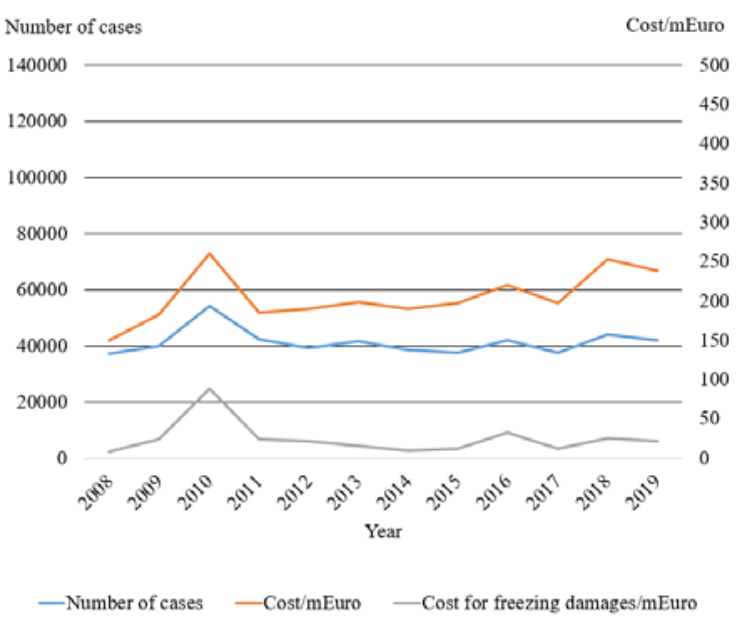

Figure 2. Number and cost of water damages cases in Norway between 2008 and 2019 [3]. 
The statistics of water damages in Denmark are gathered by the Danish building industry body, Forsikring \& Pension, for insurance- and pension companies. The water damage statistic was presented in different damage cause categories. The categories included in this study were water damages cause by inadequate pipes and connections, water damages caused by all other reasons but inadequate pipes and connections, weather and external causes, utilities and installations that are not related to weather and cold and freezing caused damages [5]. The number of reported cases, cost and cost for freezing damages in Denmark between the years 2006 and 2019 are presented in Figure 3.

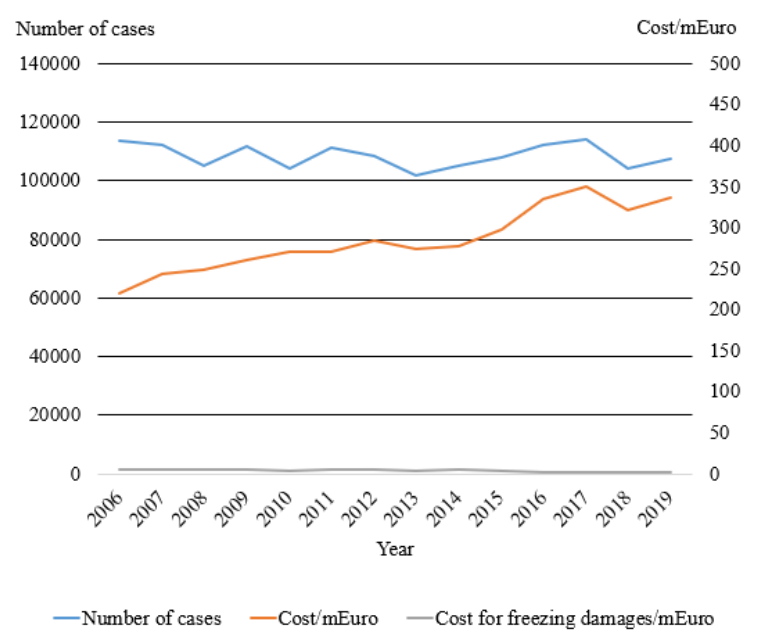

Figure 3. Number and cost of water damage cases in Denmark between 2006 and 2019 [6].

\subsection{Climate impact on freezing damages}

Water damages due to freezing each year in the Nordic countries are presented as a percentage of number of water damage cases and in relation to the mean winter temperature deviation in Figure 4. The mean winter temperature deviation are the factor that determine how much the mean winter temperature a year is deviating from the mean winter temperature for the country. The mean winter temperature is defined as the mean temperature between December, January and February and the deviation from the mean temperature for the climatological normal period 1961-1990. In Sweden, the mean winter temperature are $-4.8^{\circ} \mathrm{C}[17]$ and in Norway the mean winter temperature are $-6.8^{\circ} \mathrm{C}$ [18]. The y-axis in Figure 4 are presented with an inverted scale to illustrate the deviation of mean winter years with a mean winter temperature that are colder than the mean winter temperature.

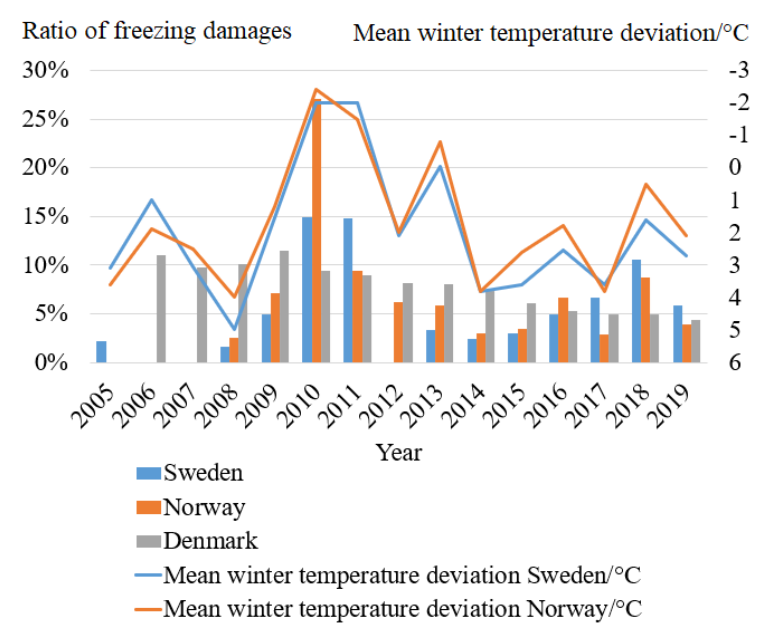

Figure 4. Ratio of water damages due to freezing in relation to the mean winter temperature deviation for the Nordic countries between 2005 and $2019[1,3,6,17,18]$.

The occurrence of water damages due to freezing in the Nordic countries was extracted from the different statistic gathering companies as the number of water damage cases. Since the number of studied cases varied between the counties and because of the different categorisation of water damages the occurrence of freezing damages was presented as percentage of all damages covered by the statistics. The figure shows the water damages that are reported to the insurance companies as a water damage due to freezing. The gaps of data from the years 2005, 2006, 2007 and 2012 are year that there was not published statistics in some countries and therefore there are no data for these years.

The impact of the climate to the statistics are an important aspect to evaluate to reduce the number of water damages due to freezing. The parameter evaluated in this study was the yearly temperature within the timespan. According to SMHI [17], the Swedish Meteorological and Hydrological Institute, the timespan studied was mostly consistent of years with a mean temperature higher than the normal mean temperature of the reference period between 1961 and 1990. The year 2010 was an exception to this relation. The statistic showed that the mean temperature this year was significantly lower than the other years studied. According to SMHI [19] the winter of 2010/11 was the coldest in since 1987 which also could be seen in the yearly winter mean temperature deviation in Figure 4.

The water damages due to freezing are presented in Figure 4 next to the yearly winter mean temperature deviation for each county according to each county's meteorology institute $[17,18,20]$. The yearly mean winter temperature deviation is an important factor to evaluate in relation to the number of freezing damage cases because of the potential impact of the climate in the cold part of the year. Hence a year with a colder winter than the mean winter temperature could show that the climate could be a factor that affects the number of freezing damages. The correlation between the 
climate and the number of freezing damages are therefore evaluated. The Figure 5 present this potential correlation.

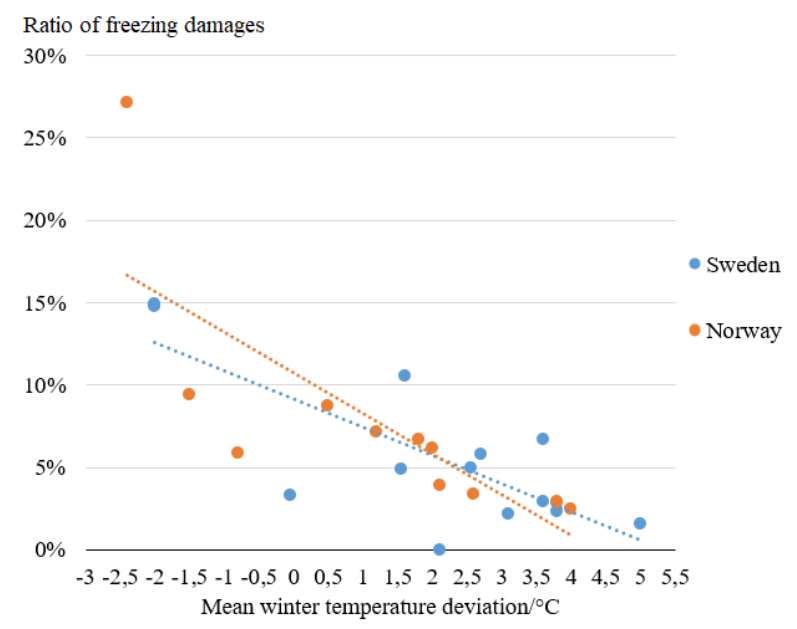

Figure 5. Correlation between the mean winter temperature deviation and the percentage of freezing damages.

The coefficient of determination $\left(\mathrm{R}^{2}\right)$ between two parameters are in this case 0.59 for freezing damages that occurred in Sweden and 0.61 for freezing damages that occurred in Norway. This indicates that the climate does have an impact on the number of freezing damages in the Nordic countries. However, the coefficient was not high enough to exclude the fact that other reasons than the cold climate could have an impact on the number of freezing damages.

\section{Discussion}

From the literature studied in this paper, it could be established that the impact of the climate in relation to water damages are not as well covered as defects in the general aspect of the building sector by the international studies. More research on the subject could be beneficial to reduce the number of freezing damages in cold climate. Researching the causes could be given more focus in the future as only limited facts of the reasons for the damages could be found in the review. However, it could also be established that the organisations and the design and construction of the buildings that have been found in the literature seems to be one of the main problems and it could also be regarded as the one of main problems for water damages. A solution to reduce the amount of water damages that occurs because of freezing could be the organisational, communication and design problems that should be solved in first-hand. This would most likely not only affect the amount of water damages due to freezing but also the whole amount of water damages in the building industry, but since the climate is not a factor that can be controlled it seems most likely that a solution for minimising the risk of freezing damages are to solve these kinds of problems that are mentioned by the studied literature.
The number of water damage cases during the latest 15 -year period seems to be constant but the costs are starting to rise which could be indicating that the complexity of building methods could be a reason for that the cost of the water damages are increasing. The empirical statistic review of water damages that occurs in the Nordic counties did also result in the statistic foundation for the study to evaluate the reported cases of water damages due to freezing in the Nordic countries. The study established that freezing damage is not an unusual damage and that it could have correlation to the cold climate in Sweden and Norway, however it seems to not be the only reason for the number of freezing damages. Other reasons that could be factors are the way that buildings are being constructed and designed but also, as mentioned in the literature review, organisational and communication problems in the building process. Some construction and design choices that could affect the buildings resistance against water damages due to cold climate are pipe insulation, building accordingly to building standards against water damage and planning of placement of pipes and connections in the building at an early stage of the building process.

The water damage statistics shows that the years 2010 and 2011 are two years with remarkable higher numbers of freezing damages. This could indicate that the cold climate of 2010 was one reason for the high amount water damages due to freezing in the Nordic counties. In a comparison between the statistics from a country with warmer climate, Denmark, and a country with colder climate, Norway, the same cold year 2010 showed that the percentage of water damages due to freezing was significantly higher in the country with the colder climate.

The coverage and the different categorization for different countries for water damages in the statistics are a problem that could be investigated further. The coverage of single-family houses are high in the Swedish statistic, but the coverage of the apartment blocks are not at the same standard. Hence, the statistic could be an overwhelming representation of damages that occurs in single-family buildings but not in apartment blocks.

\section{Conclusion}

Water damages in the Nordic countries that are covered by the statistics indicates on a decreasing amount but are still considerable with about 225000 reported cases in 2019 in the three studied counties, Denmark, Norway and Sweden. The gathered statistics shows that the percentages of water damages due to freezing constitutes between $2-27 \%$ of all the reported water damages cases in the three studied Nordic Countries Denmark, Norway and Sweden during the recent 15 years. It could be concluded, based on the results in the study, that there could be correlation between the impact of the cold climate and the number of water damages due to freezing. The number of damages due to freezing do increase a year with a winter 
with colder temperature than the mean temperature, this implies that the impact of the climate should be considered and that it need to be constructed and designed for in a larger extent.

The water damages in the studied Nordic countries amount to some 610 - 965 million Euros in insurance reimbursements each year and considering the vast amount and considering the fact of the rising costs it could be justified to establish more risk reducing actions to reduce the amount and cost of water damages that occurs each year. The water damages that occurs due to the cold climate are of importance to address due to the fact that the climate is one factor that cannot be affected by any other methods and therefore the buildings should be designed and constructed to be able to in a sustainable way endure a cold climate. 


\section{References}

[1] Vattenskadecentrum,

Vattenskadeundersökningen 2019:

Ledningssystem, utrustning, tätskikt, våtrum.

Vattenskadecentrum, 2020, p. 23.

[2] Svensk Försäkring. "Statistik om skador inom hushåll och företag." SAS Visual Analytics 7.5 .

https://statistik.svenskforsakring.se/SASVisua 1AnalyticsViewer/?reportSBIP $=\mathrm{SBIP} \% 3 \mathrm{~A} \% 2$ F\%2FMETASERVER\%2FSF\%2FExtern\%2F HOFY(Report)\&page $=$ vil (accessed).

[3] Finans Norge. "Vannskadestatistikk (VASK),."

https://www.finansnorge.no/statistikk/skadefo rsikring/vask/ (accessed).

[4] Vattenskadecentrum, "Vattenskadecentrums Skadeenkät ver. 1.1," 2020.

[5] F. Pension, "Samlet skadestatistik," 2020.

[6] Forsikring \& Pension. "Vandskader, Udviklingen $\mathrm{i}$ antallet og erstatninger for vandskader."

https://www.forsikringogpension.dk/statistik/v andskader/ (accessed)

[7] Boverket, Kartläggning av fel, brister och skador inom byggsektorn. Karlskrona: Boverket, 2018.

[8] J. Andersson and R. Kling, Bygg vattenskadesäkert : VASKA visar vägen : ett beprövat sätt att spara pengar, hälsa och miljö. Stockholm: Byggforskningsrådet, 2000.

[9] D. Johansson, J. Ericson, M. Hjalmarsson, C. Israelsson, and K. Larsen, Skadeförebyggande processer och teknik för rörinstallationer och våtrum för minskade vattenskador i byggnader. 2015, p. 105.

[10] P. E. Josephson and Y. Hammarlund, "Causes and costs of defects in construction a study of seven building projects," Automation in construction, Article vol. 8, no. 6, pp. 681-687, 1999, doi: 10.1016/S0926-5805(98)00114-9.

[11] M. Y. L. Chew and N. De Silva, "Factors Affecting Water-Tightness in Wet Areas of High-Rise Residential Buildings," Architectural Science Review, vol. 45, no. 4, pp. 375-383, 2002/12/01 2002, doi: 10.1080/00038628.2002.9696953.

[12] H. Abdul-Rahman, C. Wang, L. C. Wood, and Y. M. Khoo, "Defects in Affordable Housing Projects in Klang Valley, Malaysia," $J$. Perform. Constr. Facil., vol. 28, no. 2, pp. 272285, 2014, doi: 10.1061/(asce)cf.19435509.0000413 .

[13] W. K. Chong and S. P. Low, "Latent building defects: Causes and design strategies to prevent them," (in English), J. Perform. Constr. Facil., Article vol. 20, no. 3, pp. 213-221, Aug 2006, doi: $10.1061 /($ asce $) 0887-$ 3828(2006)20:3(213).

[14] N. Forcada, M. Macarulla, M. Gangolells, M. Casals, A. Fuertes, and X. Roca,
"Posthandover Housing Defects: Sources and Origins," J. Perform. Constr. Facil., vol. 27, no. 6, pp. 756-762, 2013/12/01 2013, doi: 10.1061/(ASCE)CF.1943-5509.0000368.

[15] S. Lee, S. Lee, and J. Kim, "Evaluating the Impact of Defect Risks in Residential Buildings at the Occupancy Phase," Sustainability, vol. 10, no. 12, 2018, doi: 10.3390/su10124466.

[16] Säker Vatten, Branschregler : säker vatteninstallation 2016:1. Stockholm: Säker Vatten AB, 2015.

[17] SMHI. "Klimatindikator - temperatur." https://www.smhi.se/klimat/klimatet-da-och$\underline{\mathrm{nu} / \text { klimatindikatorer/klimatindikator- }}$ temperatur-1.2430 (accessed).

[18] Meteorologisk institutt. "Klima fra 1900 til i dag."https://www.met.no/vaer-ogklima/klima-siste-150-ar (accessed).

[19] SMHI. "Årets väder 2010 - Kalla vintermånader." https://www.smhi.se/klimat/klimatet-da-ochnu/arets-vader/arets-vader-2010-kallavintermanader-1.15704 (accessed).

[20] DMI. "Temperaturen i Danmark." John Cappelen.

https://www.dmi.dk/klima/temaforsideklimaet-frem-til-i-dag/temperaturen-idanmark/ (accessed). 